\title{
Sergio Pitol y Fabio Morábito: la autofiguración como descentramiento del autor
}

\author{
JEZREEL SALAZAR \\ Universidad Autónoma de la Ciudad de México
}

\section{Resumen}

Este artículo reflexiona sobre la figura autoral en México a partir de dos escritores mexicanos que han elaborado, en los últimos años, obras de carácter autobiográfico: Sergio Pitol y Fabio Morábito. A partir de un análisis de El mago de Viena (2005) y El idioma materno (2014), se muestra cómo ambos autores ponen en duda las convenciones clásicas de la autobiografía y al mismo tiempo producen espacios textuales difíciles de clasificar, lo que contribuye a una noción disgregada de la identidad, una epistemología de la complejidad y una puesta en duda de las jerarquías autorales de la narración. Estas retóricas autobiográficas inestables (y las formas de figuración autocríticas que proyectan) implican representaciones diferenciadas del descentramiento del intelectual en el campo cultural mexicano, y contribuyen a modificar el estatuto jerárquico y narcisista del escritor.

Palabras clave: autofiguración, autobiografía, descentramiento, intelectual, géneros

\begin{abstract}
This article reflects on the authorial figure in Mexico based on two Mexican writers who have recently developed autobiographical works: Sergio Pitol and Fabio Morábito. The analysis of El mago de Viena (2005) and El idioma materno (2014) shows how both authors question the classical conventions of autobiography and at the same time produce textual spaces not easy to classify. This contributes to a disjointed notion of identity, an epistemology of complexity and to questioning the authorial narrative hierarchies. This unstable autobiographical rhetoric (and self-critical forms of figuration that project) involve different representations of intellectual runout in the Mexican cultural field, and help to change the writer's hierarchical and narcissistic status.
\end{abstract}

Keywords: self-figuration, autobiography, decentering, intelectual, genres 


\section{Entrada}

uando se analizan el lugar y las funciones del escritor en el espacio
público actual, suelen pasarse por alto las escrituras de carácter
autobiográfico, a pesar de que éstas, en años recientes, ocupan un amplio espectro de la industria editorial. Tal omisión se debe en parte a que la pregunta por la dimensión pública de lo literario suele responderse eligiendo textos que muestran un carácter explícitamente político. Aunque pareciera de sentido común hacerlo así, me parece productivo ponerle atención a ciertos discursos asociados tradicionalmente a la vida privada. La manera en que se autofiguran distintos escritores en textos que tienen como centro al yo ofrece un buen indicio de cómo se ha transformado la percepción de su tarea en la sociedad, es decir, nos puede ayudar a comprender la idea de intelectual que rige sus proyectos literarios. Así, la representación de la escritura y de la lectura en textos autobiográficos recientes (ya sea a través de escenas de lectura o mediante recursos que dan cuenta de una imagen del escritor como intérprete) responde no sólo a ciertas formas de la subjetividad contemporánea, sino al lugar colectivo que la sociedad le otorga al creador en la actualidad.

Para indagar en ello, me interesa analizar la compleja figuración que practican dos escritores mexicanos cuyos proyectos escriturales resultan significativos y reveladores: Sergio Pitol y Fabio Morábito. Pertenecientes a generaciones distintas, encuentro coincidencias o similitudes en los procedimientos que practican, en las poéticas heterodoxas a las que se adscriben y en el estatuto descentrado que le otorgan a la figura del letrado. No obstante tales semejanzas, es necesario puntualizar por separado sus propuestas individuales, de modo que sea posible comprender también las diferencias que hay en los tipos de hibridación que practican y en el modo en que tales moldes evidencian descentramientos del autor con sus propias peculiaridades. Para ello me concentraré en dos libros en particular, El mago de Viena de Pitol (publicado en 2005) y El idioma materno de Morábito (que apareció en 2014), aunque haré constante referencia a otros textos de los mismos autores que dialogan con estas obras. 


\section{La autofiguración desplazada de Sergio Pitol}

Los últimos libros de Sergio Pitol, inscritos en la literatura del yo y vinculados a la recuperación de la memoria, forman parte de una constelación de obras literarias que recientemente han puesto en crisis la frontera tradicional entre ficción y no ficción. Caracterizado por desestabilizar la relación entre el autor y su representación textual, El mago de Viena permite no sólo dudar del supuesto carácter referencial de todo registro autobiográfico, sino también mostrar el tipo de anfibología textual que Pitol ha practicado desde la aparición de El arte de la fuga en 1996.

Desde que uno abre las páginas de El mago de Viena se percata de que el libro posee un fuerte componente confesional, pero que la idea de lo autobiográfico no adquiere aquí una formulación tradicional ni fija. Son muchas las ambigüedades que muy pronto hacen del libro una incógnita a resolver. Simula un cuaderno de notas, sin fechas de por medio, en donde los fragmentos se van sucediendo uno tras otro. Cada fragmento inicia con letras capitales, a manera de breves títulos incorporados al primero de los párrafos. Entre un fragmento y otro puede haber conexiones o no; cuando las hay, en la mayoría de los casos no resultan evidentes, pero existe siempre un tono común, ciertos temas que tienen más adelante líneas de continuidad, además de que permanece a todo lo largo del libro la voz aparentemente estable del narrador, quien recuerda periodos de su vida, lecturas, encuentros... de modo que el lector percibe la unidad autobiográfica del conjunto.

No obstante, el libro también puede parecer un conjunto de ensayos literarios, pues el narrador no sólo hace constantes comentarios sobre libros y autores, sino que elabora reflexiones relativas a la creación literaria, el papel de la literatura en el mundo, la importancia de la lectura... y establece interpretaciones precisas en torno a ciertos autores y a ciertas obras. La recepción del libro por parte de la crítica ha propuesto otras posibles caracterizaciones para este texto, pensándolo incluso desde la ficción. Christopher Domínguez afirma que se trata de "una de las grandes autobiografías literarias de nuestras letras" (2007: 415), la cual muta "de la novela al ensayo" (2007: 414). Por su parte, Juan Villoro sostiene que el tipo de escritura que practica Pitol, a partir de la publicación de $E l$ 
arte de la fuga, posee "el rostro ambivalente de la ficción memoriosa" (2000: 55). Como se ve, la ambigüedad genérica del libro hace dudar a sus lectores, sobre todo a aquellos que perciben los rasgos ficticios y autoparódicos de algunos de sus fragmentos, como Alfonso Montelongo, quien argumenta la existencia de relatos en su interior (2007: 107).

Consciente de ello, al referirse a la forma de este tipo de obras, el propio Pitol señala en la introducción a sus Escritos autobiográficos lo siguiente: "En esta fuga de géneros literarios casi todos los ensayos se imbrican con algún relato. El ensayo y la narración se unifican" (2006c: 11). Más que la invención de un nuevo género literario, lo que vemos en Pitol es la solución a una disputa creativa entre textos dominados por una fuerte autoconciencia en torno a los recursos de la creación, y un afán por volver narrativa toda forma de reflexión.

Al explicar cómo escribió su primera novela, El tañido de una flauta (1972), el narrador de El mago de Viena afirma:

El terror de crear un híbrido entre el relato y el tratado ensayístico me impulsó a intensificar los elementos narrativos. En la novela se agitan varias tramas en torno a la línea narrativa central; tramas importantes, secundarias, y algunas positivamente mínimas, meras larvas de tramas necesarias para revestir y atenuar las largas disquisiciones estéticas en que se enzarzan los personajes (2006b: 232-233).

Si uno lee El tañido de una flauta puede comprobar que desde sus inicios Pitol tenía una fuerte tendencia a dilatar las tramas en favor de la reflexión, la cual casi siempre se expresaba a través de elementos metadiscursivos. Llama la atención cómo Pitol califica tal impulso en términos negativos: "El terror de crear un híbrido". De esa misma relación conflictiva nace El mago de Viena: el recelo de publicar un libro de ensayos aburrido, tradicional y estático (un libro contrario a su carácter explorador, excéntrico y paródico), lo lleva a experimentar formalmente con él. Así lo confiesa en una entrevista: "El mago de Viena iba a ser un conjunto de artículos, de prólogos y textos de conferencias. Pero al ordenarlos en un índice me pareció muy fastidioso. Comencé a retocarlos, buscar una estructura narrativa, hacer de esos materiales algo como una novela o una 
narración autobiográfica, con un tono celebratorio y levemente extravagante" (Monsiváis 2008: 14).

Como si combatiera conscientemente la tendencia a la reflexión y a la crítica de textos, Pitol ha pensado sus obras bajo el ideal narrativo de la novela, pero paradójicamente no ha podido anular el impulso ensayístico que siempre lo acompaña, debido a la gran autoconsciencia que posee como escritor. En esta tensión intrínseca se encuentra buena parte del atractivo de su obra. Vista desde esta perspectiva, su historia es la del escritor que se la ha pasado buscando una forma de conciliar dos sistemas de escritura tradicionalmente concebidos como opuestos. Lo significativo es que quizá El mago de Viena sea donde mejor hace convivir esta escritura dual, bajo el engrudo de lo autobiográfico. De ahí mi interés en este texto. Si es verdad que en sus novelas Pitol ya había practicado un tipo de autofiguración paródica (López, 2015: 134-180), mi interés es explorar cómo funciona y qué significa la representación del yo que proyectó en la etapa de su obra en que la novela dejó de constituir el género central de su producción. La desestabilización genérica de El mago de Viena remarca aspectos que en sus novelas resultaban sólo subterráneos: tiene repercusiones tanto sobre la naturaleza de la memoria como sobre la imagen y los límites del yo representado. Comienzo por esto último.

Pensados desde la perspectiva de lo autobiográfico, los escritos recientes de Pitol han sido considerados como ejercicios parciales, en la medida en que no terminan de revelar la vida del autor. Humberto Guerra, por ejemplo, acusa a Pitol de ser un "autobiógrafo reticente" (2007: 318), pues en lugar de ofrecernos un recuento vivencial nos borronea "su propia imagen" (2007: 319). En esta clase de lectura persiste el supuesto de que la escritura autobiográfica implica una dimensión cognoscitiva que nos permitiría acceder a la subjetividad y al pasado del autor. Justo contra ese supuesto "valor objetivo del texto autobiográfico" (Loureiro 1991: 5) es que Pitol escribirá sus textos y los cargará de ambigüedad.

Ricardo Piglia escribió que "La crítica es la forma moderna de la autobiografía. Uno escribe su vida cuando cree escribir sus lecturas [. . .] El crítico es aquel que encuentra su vida en el interior de los textos que lee" (1999: 137). El mago de Viena pareciera estar diseñado para demostrar tal postulado, pues en él la autofiguración del narrador está asociada a la experiencia literaria, 
pero sobre todo a su experiencia como lector. O por decirlo de otro modo, en Pitol lo autobiográfico toma la forma de un recuento de lecturas. De hecho, la dimensión confesional en El mago de Viena se encuentra vinculada a lo que podríamos considerar una teoría de la lectura diseminada a lo largo de la obra. Si lo más íntimo se produce en el contacto con los libros es porque a través del acto de leer se genera un espacio donde lo privado y lo público se enlazan y dialogan.

Pitol utiliza diversos mecanismos para hacer de la escritura del yo un espacio dialógico en donde intimidad y vida pública conviven. Uno que puede detectarse de manera constante, y que está vinculado a sus modos de leer, consiste en lo que podríamos denominar una autofiguración desplazada. El narrador de El mago de Viena valora en otros autores aquellas experiencias que le parecen comunes o aquellas formas estéticas que él también practica. Sobre la escritura de Gao Xingjian, por ejemplo, afirma lo que un lector podría decir sobre cualquier novela de Pitol: "La trama es un intrincado tejido de discursos, un laberinto que yace bajo una superficie en apariencia confusa" (2006b: 73). Hablar de otros escritores le permite conformar su propio autorretrato, gracias a un ejercicio de identificación y contraste. El desplazamiento hacia el otro le sirve a Pitol para autofigurarse. Es como si sólo distanciándose pudiera hablar de su propia vida. "Persistentemente me convierto en otro", afirma hacia el final del libro (2006b: 221). En otras ocasiones habla de sí mismo en tercera persona, ya sea para remarcar la distancia entre el yo presente y el yo pasado, o para jugar con las expectativas del lector.

Evadir la primera persona en un texto autobiográfico tiende a sugerir la idea de una identidad no unívoca, en la medida en que se halla desplazada. De tal modo la personalidad estaría construida a partir de metamorfosis y disfraces que pondrían en crisis el pacto de confianza que la concepción tradicional de la autobiografía carga consigo. Para Pitol, la persona lo es en su sentido etimológico: una máscara, de modo que tanto la idea de sujeto como de sinceridad no resultan simplificadas, sino que implican un proceso complejo que es celebrado a través de la mutación y el antifaz.

Otro elemento que desestabiliza el contrato de lectura tiene que ver con la frontera entre textos de ficción y de no ficción. En distintos lugares, Pitol 
ha afirmado la porosidad de la frontera entre ambas dimensiones, a veces remarcando la carga de ficción que hay en toda realidad y otras veces otorgándole un poder de veracidad mayor a los textos ficticios que a los de carácter referencial. Sus textos autobiográficos están plagados de efectos contrastantes, en la medida en que existe una literatura del yo fuertemente afirmada a través de un narrador cuya veracidad suele ponerse en duda: "De la única influencia de la que uno debe defenderse es la de uno mismo" (Pitol, 1996: 180). En ciertos momentos de El mago de Viena, este ejercicio de autodescalificación se inscribe en fragmentos plenamente ficticios. Es el caso de "Hasta llegar a Hamlet", en donde el narrador, para reflexionar sobre los poderes de la relectura, construye un personaje cuyo nombre (Gustavo Esguerra) no corresponde con el del autor ni el del narrador, pero cuya personalidad coincide en lecturas, vivencias y manías con las de Pitol. Así, lo que en principio parecía una reflexión de corte ensayístico sobre la relectura, pronto se vuelve un fragmento con signos autobiográficos y al final se revela como un juego de autofabulación. Se trata de una nueva manera de enmascararse. Como afirma Piglia, "recordar con una memoria extraña es una variante del tema del doble pero es también una metáfora perfecta de la experiencia literaria" (1999: 66).

Esta ruptura de la identidad nominal entre autor, narrador y personaje (el pacto autobiográfico al que se refiere Phillipe Lejeune) y el intento por dar cuenta de una falsa memoria, ocurre en otros fragmentos que incorporan estrategias lúdicas, paródicas y metadiscursivas, los cuales pueden ser leídos como ejercicios autoficcionales en donde se construye un pacto ambiguo (Alberca, 2007: 48-49), un pacto de vacilación (Louis 2010: 73) o una narración paradójica (Casas 2010: 193). Más allá del modo en que se defina a este tipo de contratos de lectura ambivalentes, lo cierto es que operan bajo el signo del autoescarnio: los personajes ficticios que Pitol introduce en El mago de Viena funcionan para ironizar sobre sí mismo. Dice Villoro que en muchos textos "Pitol se descalifica como testigo veraz de los sucesos" (2000: 56). La idea de un "narrador bajo sospecha" (Casas 2010: 205) apunta a otra de las posibilidades de lectura que ofrece esta obra: la intención de remarcar la imposibilidad de todo proyecto autobiográfico en su sentido tradicional. 
Se ha dicho que en las tramas de sus relatos y novelas siempre hay un enigma que no se resuelve, pero del que depende toda la estructura de la obra y el destino de los personajes. Ocurre lo mismo aquí. En la estética de Pitol, la realidad tiene un sustrato inaccesible:

Cuando escribo algo cercano a la autobiografía, sean crónicas de viajes, textos sobre acontecimientos en que por propia voluntad o puro azar fui testigo, o retratos de amigos, maestros, escritores a quienes he conocido, $y$, sobre todo, las frecuentes incursiones en el imprevisible magma de la infancia, me queda la sospecha de que mi ángulo de visión nunca ha sido el adecuado, que el entorno es anormal, a veces por una merma de realidad, otras por un peso abrumador de detalles, casi siempre intrascendentes. Soy entonces consciente de que al tratarme como sujeto o como objeto mi escritura queda infectada por una plaga de imprecisiones, equívocos, desmesuras u omisiones [...] De esas páginas se desprende una voluntad de visibilidad, un corpúsculo de realidad logrado por efectos plásticos, pero rodeado de neblina (2006b: 220-221).

Pensar lo autobiográfico desde este punto de vista implica modificar sus principios y formas. Lo que defiende Pitol es una epistemología de la incompletud, que adquiere forma en sus textos autobiográficos a través de su secuencia fragmentada, pero sobre todo mediante una serie de supresiones y saltos temporales que impiden que la vida que relata tenga una textura homogénea y cronológica. Este quiebre de la linealidad narrativa explica por qué cada una de sus obras no busca dar cuenta de la totalidad de la vida de su narrador; en su lugar, refiere sólo episodios aislados o momentos significativos que se enlazan gracias a la lógica del azar y la libre asociación.

Si Pitol trabaja con lo suprimido es porque busca demostrar que todo ejercicio de autoexégesis resulta imposible. O mejor aún: indeseable. El autoconocimiento no debe ni puede ser el resultado de las escrituras del yo. Para Pitol la interpretación en torno al mundo es siempre cambiante, lo mismo que la identidad de los sujetos: nuestro carácter móvil e inasible impide que podamos conocernos de manera plena. Por eso, la memoria en Pitol adquiere la forma de una serie de juegos con la identidad, en donde muchos yos expresan sus 
múltiples posibilidades vitales, lo cual deja ver el artificio constitutivo de todo relato de la subjetividad. Para Pitol, más que esencia estable, toda identidad es el proceso (complejo, múltiple, itinerante) de búsqueda que un sujeto realiza para constituirse a través del lenguaje.

Aunado a esto, en El mago de Viena es claro que la memoria se concibe como un espacio promiscuo e infiel que no puede proveernos de verdades estables. "Un atributo de la memoria es su inagotable capacidad para deparar sorpresas. Otro, su imprevisibilidad" (2006b: 75), afirma el narrador. El azar de los recuerdos y la serie de ficciones continuas que la memoria genera impiden su estabilidad. Recordar, desde la perspectiva de Pitol, sería entonces un ejercicio de asociaciones azarosas, cuyo sentido estaría dado por las necesidades narrativas de quien en un momento dado lee su propio pasado; pero esta lectura reiterada siempre termina caducando y se modifica insistentemente con el tiempo. Si la memoria no puede ofrecer un sentido de totalidad y permanencia, no es extraño que los libros autobiográficos de Pitol sean fragmentarios y construidos a través de saltos, elipsis y desplazamientos. Las versiones en torno al pasado tienden a multiplicarse, por eso la escritura de la memoria resulta infinita. Prueba de ello son su Trilogía de la Memoria (2007), así como su autobiografía de 1966 (Pitol, 1967), reescrita un par de veces (Pitol 2006a; 2011). Lo único que podemos tener son, entonces, autobiografías inacabadas, oblicuas, múltiples y cambiantes.

De ahí que Pitol no haya dejado de publicar libros con esta forma: al interior de un mismo volumen narra varias veces el mismo episodio y en la suma de los libros estas reiteraciones se diversifican. Se trata de variaciones sobre variaciones, en donde incluso muchos párrafos son reutilizados, pero obtienen otros matices al ser recontextualizados en otro volumen. Esta reorganización que constituye una suerte de arte combinatoria es muy clara en uno de sus últimos libros: Una autobiografía soterrada. Llama la atención el artículo una en el título, pues remite a la multiplicidad y variedad de escrituras autobiográficas que practica Pitol. El subtítulo es igualmente significativo: "Ampliaciones, rectificaciones y desacralizaciones". Para Pitol, no hay ediciones definitivas y esto responde al tipo de representación literaria que quiere formular en torno a la memoria. No es posible escribir una versión concluyente e irrebatible en torno al pasado y en torno a la propia subjetividad. La narración del yo será siempre inacabada y, 
por supuesto, descentrada. En ese sentido, para Pitol todo texto autobiográfico debe ser una ficción de memoria (Neumann, 2008), debe intentar representar sus formas y sus límites, sus fallas y sus misterios. Es en la "fuga de géneros" y en la reescritura de éstos en donde Pitol encuentra la mejor formulación de tales objetivos.

\section{Fabio Morábito, un yo desterritorializado}

Aunque perteneciente a una generación distinta, en la escritura de Fabio Morábito son legibles algunas de las estrategias que he descrito como prácticas constantes de Pitol, pero poseen su propia especificidad y lidian con el descentramiento del yo de modos distintos. Para empezar detengámonos en las similitudes. En El idioma materno (2014) también vemos la voluntad de hibridación asociada a un pacto de lectura ambivalente. Conformado por ochenta y cuatro breves apartados, el libro puede ser leído como un conjunto de ensayos y de relatos, como un volumen de poemas en prosa o como un arte poética. Por supuesto, es todo a la vez. Elijo, sin embargo, interpretarlo aquí desde el ángulo de lo autobiográfico, no en su sentido convencional, pero sí con la heterodoxia que ha adquirido el "género" en los últimos años. Hay en él voluntad de registro y reordenamiento de la propia existencia, alteración narrativa de la memoria, experiencia del análisis, proyección de una subjetividad... en suma, la construcción de un autorretrato - o muchos.

En El idioma materno, Morábito intercala la narración y el análisis de momentos vitales con otros registros muy cercanos al ensayo y, de manera menos marcada, al relato. Lo autobiográfico resulta así acotado o flanqueado por reflexiones y pequeñas historias de carácter ficticio, de manera que el género se vuelve anfibio: la escritura del yo se confunde con el cuento, y las memorias, con el microensayo. Es claro que Morábito no se propone una autobiografía estricta: no desea "narrar la historia de su personalidad", como quería Lejeune (1994: 50), ni conocerse a través del recuento escrito sobre lo vivido; pero al ponernos en contacto, una y otra vez, con su memoria y sus hábitos (virtudes y vicios incluidos), no deja de construir una figuración de sí mismo. 
Esta tendencia a la introspección y a la amalgama de géneros ya estaba presente en otros de sus libros, especialmente en También Berlín se olvida (2004), en donde aparecen crónicas, ensayos y relatos de viaje vinculados con el año que vivió en Alemania. De igual modo, Morábito había practicado formas de figuración en donde la imagen del letrado estaba puesta en el centro. Los cuentos "El valor de roncar", "Las puertas indebidas" y "Los búlgaros", incluidos en Grieta de fatiga (2006), muestran imágenes complementarias del escritor; otros relatos anunciaban las nociones de intelectual con las que trabaja Morábito a través de distintas figuras del lector: el traductor en "Los Vetriccioli" (en La lenta furia, 1989b), el corrector de estilo de "Las correcciones", el filólogo de "La cigala" y el descifrador de "Los crucigramas" (en Grieta de fatiga). No obstante, lo particular de El idioma materno es que, al no tratarse de un libro cuyo contrato de lectura remita al de la ficción, muestra de manera más clara el tipo de autofiguración que Morábito se propone, a la hora de conjugar autoexamen y heterogeneidad genérica.

En Morábito, la autonarración se expresa atravesada por un carácter apelativo en donde la asociación libre sirve como engrudo para la vinculación de anécdotas personales, recuerdos del pasado y reflexiones que buscan sostener distintas interpretaciones en torno a la escritura, a la comunicación y al lenguaje en general. Es como si escucháramos el modo en que un escritor intenta comprender sus experiencias cotidianas y su pasado a partir de los conocimientos lingüísticos que posee y la experiencia que detenta como poeta y narrador. Se trata de una retórica del pensamiento que evita reiteradamente caer en la conceptualización; por el contrario, construye imágenes precisas como un método para poner en escena las ideas que desea transmitir, y para plantear el modo en que tal reflexión lo constituye como sujeto. Aquí ya se notan las diferencias escriturales respecto a la obra de Pitol. En un fragmento titulado "Desconfianza en el oído" el narrador de El idioma materno relata sus dificultades auditivas y, al mismo tiempo, cavila sobre el deletreo de las palabras, sobre el modo en que las volvemos abstractas al pasarlas por el registro mental de la escritura: 
cuando alguien nos deletrea un nombre o una palabra, nos está matando, porque nos excluye del lenguaje [.. . L La palabra es entera como un soplo. Cada vez que deletreamos para oír mejor, detenemos ese soplo y nos separamos del mundo [.. . ] la escritura es la venganza de los sordos, una artimaña que nos ha hecho desconfiar de la palabra desnuda, la palabra que se oye, y nos hace recelar de nuestro oído (Morábito, 2014: 49).

Contra la "tiranía del concepto" (2014: 24), Morábito construye analogías, símiles y metáforas que le permiten proyectar la imagen de un yo vinculada al lenguaje, y hablar de éste como una experiencia compleja que va más allá de la letra escrita:

Es por la escritura que ha surgido la palabra como la soberana indiscutible del lenguaje, junto con la creencia de que hablar consiste en encadenar palabras. Sabemos que no es así, que hablar es algo parecido a saltar sobre las piedras de un torrente, donde pisamos sólo algunas piedras, aquellas que nos permiten saltar hacia las otras. Sólo gracias a esa relativa refutación de cada piedra podemos cruzar hasta la otra orilla (2014: 50).

Una y otra vez, el libro apuesta a favor de la polisemia de la palabra poética y arremete contra la cerrazón de un lenguaje concebido como cierre conceptual o fijación del signo sobre la página. De ahí que relate escenas en donde la comunicación se da a través de los gestos y los sentidos, el grito o el silencio.

El idioma materno es un libro habitado por personajes que establecen relaciones extremas y físicas con el lenguaje: hay sordos y mudos que se comunican con el tacto, parejas que se enamoran con los ojos cerrados o cuya potente gestualidad las vuelve más interesantes, sujetos que leen caminando, intercalan la lectura con la violencia física o la meditación en un jardín y hasta quien patea un libro como acto de catarsis extrema. En todos los casos, el lenguaje no aparece como simple sucesión de palabras, sino como experiencia material y existencial, en muchos casos acústica y hasta olfativa:

Recuerdo esta frase leída en alguna parte: "Los submarinistas aborrecen el ruido". También lo aborrecen los escritores, o mejor dicho, la escritura; de hecho, un escritor puede escribir en medio del ruido y a veces hasta lo 
necesita, pero la escritura es incompatible con él; lo que ocurre es que un escritor logra aislarse del ruido que lo rodea y éste le sirve en la medida en que lo obliga a concentrarse en lo que escribe. Porque lo que escribe, lo escribe en silencio. La ficción necesita doble vidrio. El estilo es la capacidad de aislarse, la expulsión del bullicio exterior (2014: 135).

A la opresión del lenguaje abstracto, Morábito le opone la corporalidad, la reflexión mediante imágenes, los afectos y el regreso a los registros más diversos del habla oral. Gina Saraceni ha estudiado las formas en que Morábito, sobre todo en la poesía, trabaja con la materia acústica para hablar de cómo hay experiencias del mundo que son intraducibles a la escritura (2015: 57). El idioma materno remarca los sentidos (el oído, el tacto, el olfato, la vista y el gusto) porque éstos consignan la materialidad del lenguaje, quebrando toda noción abstracta en torno a la comunicación. La escritura resulta así no una simple sucesión de palabras, sino una vivencia física que involucra toda nuestra fisonomía. Esto es muy visible cuando reflexiona sobre la poesía:

Antes de decir lo que dice, de comunicar una idea o una experiencia, un poema es una ruptura de la dicción acostumbrada, un balbuceo liberador, la reminiscencia de un idioma - el verdadero idioma materno- proveedor de todas las articulaciones posibles, o sea de todas las muecas. Sí, porque el placer que nos causan la rima y las aliteraciones [...] es de la misma clase del que nos lleva a estirar y a contraer la cara [...] en los talleres de poesía debería trabajarse con la mímica y el dislate facial, acompañados de la emisión de sonidos de toda clase [...] a fin de dilatar el espectro de nuestro aparato emisor, a la par que el de nuestro oído y, de este modo, rearticular músculos y nervios olvidados para diversificar nuestra cara [. . .]. La poesía, pues, como un vivificador no sólo de la prosa y del idioma, sino también del semblante (2014: 61-62).

Morábito no sólo instituye lenguajes del cuerpo. Cuando el libro remite a la traducción, el poliglotismo, el diccionario o las experiencias personales con otras lenguas, remarca la arbitrariedad de los signos y los límites que posee el lenguaje para narrar experiencias y representar el mundo. Ya en También Berlín se olvida esto servía como motivo central de la reflexión, pero también en varios 
de sus cuentos el tema de la intraducibilidad y la impotencia del lenguaje aparece una y otra vez, por ejemplo, en el segundo libro de cuentos de Morábito, La vida ordenada (2000), donde cada historia remite a un enigma que el narrador no logra descifrar. Por su parte, en El idioma materno las vivencias relatadas apelan en muchos momentos al modo en que la representación no depende de los objetos (del referente real), sino de los sujetos y los efectos de realidad que el lenguaje les procura en términos simbólicos; en ese sentido, remarca lo artificioso de sostener la equivalencia entre el signo y su referente, entre las palabras y las cosas:

Aprender a escribir con vocablos que carecen de un referente preciso, que no remiten a ningún objeto y a ninguna idea y que, como las piedras de los ríos, han perdido su significado a fuerza de tanto frotamiento, les enseñaría a los niños a valorar el sinsentido de las palabras, a repetirlas sin más, con perplejidad o alegría, lo que afinaría su capacidad conjetural, idiomática y, de paso, su oído [. . .] Nada como esos nombres grabados en las lápidas (los más puros que hay, porque con ellos ya no se llama a nadie) para intimar con el sonido de las palabras [. . .] Sólo esos nombres, al no tragarse la mentira de la equivalencia y de la semejanza, nos proporcionan a base de lenguaje la salida del lenguaje, el atisbo de la realidad del mundo (2014: 23-24).

Estas reflexiones sobre las complejidades de la representación son importantes para comprender la autofiguración que propone el texto. No se trata solamente de pensarse como escritor o especialista en temas lingüísticos, sino en señalar cómo contar la propia vida implica asumir la dificultad de hacerlo, pues toda identidad supone una experiencia con y a través del lenguaje. Poner en duda esa transparencia de la escritura implica en el fondo descalificar un supuesto básico de la autobiografía clásica: la noción de que el sujeto puede dar cuenta de la verdad de su vida a partir de un principio de sinceridad. Aquí lo que reina es el estupor maravillado, la fascinación ante lo que no es posible aprehender.

Al comentar las perplejidades de La vida ordenada, Geney Beltrán afirma que "aunque el domicilio es incierto, la mirada narrativa sigue siendo precisa, fija. Morábito no se inclina por hacer uso de técnicas que mimeticen en el 
estilo o la estructura esa inestabilidad" (Beltrán, 2015: 38). Tal afirmación no es compatible con El idioma materno, donde la autenticidad está cuestionada no sólo a través de reflexiones, sino mediante estrategias formales que remiten a la forma fragmentaria y heterogénea del texto. El "uso intensivo del comentario interno" (lo que le otorga al libro su apariencia ensayística), la yuxtaposición de narraciones autónomas escritas en tercera persona y apartados en primera persona (a la manera de autorretratos múltiples), la estructuración no cronológica sino temática y fragmentada de los capítulos, así como la inestabilidad genérica del volumen en su conjunto, dan cuenta de una autofiguración heterodoxa y problemática, que vuelve manifiestas las complejidades de la autonarración.

El yo que se proyecta en El idioma materno, además de fracturado y no lineal, está miniaturizado: cada pieza se presenta como un autorretrato diminuto - aunque no lo sea a cabalidad-. Morábito ya había practicado la estrategia de escritura en serie en esa suerte de bestiario heterodoxo titulado Caja de herramientas (1989a), también marcado por la ambigüedad genérica. Lo que aquí resulta novedoso es que la serialidad está asociada a los recuentos del yo, y que incluso cuando se introduce un relato autónomo o se toma distancia de ese yo, las reflexiones sobre la naturaleza del lenguaje y de la representación le otorgan nuevos significados a la autofiguración.

Esto se aprecia en una preocupación que aparece de forma continua en el libro, la relación problemática (e irresoluble) entre apropiación e identificación: ¿cómo nos determina y diferencia el idioma propio?, ¿a quién pertenece la escritura?, ¿de qué modo el trato que establecemos con el lenguaje nos vuelve otros? Estas interrogantes se reformulan de distintos modos a lo largo del libro, a través de una serie de leitmotivs: el escritor como ladrón que se apropia de lo que en el fondo es social, la poesía como recuperación de un extrañamiento cuyo origen es el asombro infantil, la lectura como metamorfosis o como forma de identificación a partir de lo ajeno, el acceso a otras lenguas como paradójicas formas de la traición y de la salvación.

Respecto a lo último, llaman la atención los ejercicios de apropiación y desapropiación que aparecen en múltiples ocasiones vinculados a la lectura o a la expresión oral. Al hablar sobre su biblioteca, el narrador afirma el valor de uso de los libros: "Ahí donde advertimos un hueco en nuestra biblioteca [...] 
se justifica que tomemos la pluma para, de la manera más decorosa posible, escribirlo nosotros" (2014: 20); de igual modo, relata su imposibilidad de retener volúmenes que considera mercantilmente valiosos o los que no se asocian con una vivencia íntima:

mi biblioteca no tiene nada de hercúleo, siendo harto modesta, tanto en cantidad de libros como en rarezas. Cuando ha caído en mis manos algún libro raro, de esos que hacen la delicia de los coleccionistas, lo he regalado en seguida. Carezco del menor orgullo bibliófilo y me aterran esas grandes bibliotecas que a la muerte de su dueño son adquiridas por alguna fundación o universidad. Un escritor de narrativa o de poesía que posea más de mil libros empieza a ser sospechoso (2014: 20).

Además de anticoleccionista, el narrador se autofigura como traidor y ladrón. Desde el primer fragmento, titulado "Scrittore traditore", nos hallamos ante un sujeto que despliega su memoria estableciendo una perspectiva crítica frente a su pasado. En estas remembranzas contrarias a la idealización, el narrador da cuenta de una serie de confesiones criminales, la primera de las cuales es ya una ficción de origen: traiciona los sentimientos que tenía hacia un compañero frágil, débil y femenino, porque le es imposible serle infiel a la literatura. De igual modo, al robar dinero a sus padres para ir al cine, descubre los orígenes de su vocación como escritor. Así, la ruptura de normas morales no sólo queda vinculada a la actividad creativa, sino que permite justificar los mecanismos de la apropiación: "No me arrepiento pues de esos hurtos y pienso incluso que habría que enseñar en los talleres literarios a robar pequeñas cantidades de dinero, porque cuando se escribe con intensidad se está en realidad robando, sustrayendo de los bolsillos del lenguaje las palabras necesarias para aquello que uno quiere decir, justo esas palabras y ni una más" (2014: 14).

En el fondo, el lector se halla frente a relatos sobre la pérdida de la inocencia que remiten siempre a la constitución de un estilo: no se puede escribir de manera ingenua. De ahí que la autofiguración no sea del todo negativa, sino ambigua. Cuando remite a otro tipo de infidelidades o traiciones (un personaje reniega de su lengua materna, otro roba a sus amigos los libros de sus bibliotecas), siempre existe un rasgo positivo que permite resignificar los hechos, de modo que éstos 
operan como ejercicios de liberación o hallazgo. El cierre del volumen es, en ese sentido, paradigmático:

[...] el extranjero más extranjero de todos es aquel que escribe en otro idioma, en virtud de una doble extranjería: la de la escritura, que es una traición al mundo, y la de escribir en una lengua que no es la materna, que es una traición al habla. Pero tal vez en esta traición a la lengua de origen radica la sola salvación posible, el único perdón al que puede aspirar un escritor por haberse apartado del mundo y del habla. Porque todo escritor, bien visto, se hace escritor gracias a esta traición, se aparta de la lengua madre para adoptar una lengua que no es la propia, una lengua extranjera, una lengua sin lágrimas. Se abdica del idioma materno porque se abdica del llanto y se abdica del llanto porque sólo dejando de llorar se puede escribir (2014: 178).

Hay que recordar que Morábito optó por escribir sus obras en español, cuando su lengua materna era la italiana. Tal decisión subyace a varias de las reflexiones presentes en el libro, de modo que la extraterritorialidad (Steiner, 2002) aparece como un elemento constitutivo de la obra. En "El idioma solitario" y en "El gran políglota" se exploran los riesgos que alcanza tal ejercicio desplazado o extremo de las lenguas: la soledad o la mudez lingüísticas. El tema de la traducción y de la posibilidad de entablar un diálogo con el otro (o lo otro) es aquí central. "No es posible hablar exclusivamente un solo idioma. [. . .] Sólo podemos hablar porque nuestro idioma no está solo" (2014: 70), afirma el narrador. El lenguaje (en tanto espacio donde se construye la identidad y la alteridad) es para Morábito un puente difícil de cruzar; él lo intenta a través una serie de estrategias de apropiación a partir de las cuales se busca desplazar (¿despedazar?) al yo, intercalando modos discursivos diversos o narrando historias ajenas. Eso explica la reescritura de relatos clásicos que aparecen en el libro (El caballo de Troya, Pulgarcito, Don Juan...) o el énfasis en pensar ciertas formas de la escritura que implican el contacto con la otredad, la riqueza de la diversidad (lingüística) o la identificación con el prójimo (la traducción, la corrección, el subrayado, la reutilización de cuadernos...). 
El título mismo del libro apunta al vínculo inquebrantable entre lo colectivo y lo íntimo, entre lo que nos identifica y lo que nos vuelve diferentes. De manera implícita, la expresión "el idioma materno" recupera una pregunta que ha sido cara a la escritura autobiográfica: ¿quién soy yo para los otros? Las respuestas que ensaya Morábito a lo largo de las páginas no son tajantes e implican siempre experiencia colectiva, desplazamiento, alteridad: "Uno se hace escritor el día en que encuentra un yo postizo que viaja modestamente en el carril de acotamiento para no despertar al otro, el que ocupa el carril central" (2014: 140). Por ello no resulta sorprendente que lo autobiográfico en Morábito adquiera cierto carácter descentrado: "Hacerse escritor es deslizarse hacia el borde, volverse un tanto anónimo y escurridizo, menos genuino y profundo, que es el precio principal que hay que pagar en este oficio" (2014: 140).

Si Morábito sitúa al escritor en un "carril de acotamiento", también el lector tiene en su libro una figuración inestable. Contraria a la imagen del lector extremo (aquel que sacrifica la salud, el descanso o la vida misma, con tal de leer y acceder a la "verdadera" vida), la imagen del lector que prevalece en El idioma materno es la de un sujeto que lee de manera azarosa, inacabada e indirecta. En "Anna Karenina", la decisión de leer se produce no por compromiso intelectual o pasión íntima, sino para evitar el aburrimiento. De igual modo, en "El velador de Vallejo" el narrador no teme confesar que se ha especializado en el poeta sin haber leído uno sólo de sus poemas. Más allá de que en algunos casos se trate de ironizar en torno a la condición de la lectura contemporánea (como en "Nadie lee nada"), hay aquí una figuración que remite al intelectual contemporáneo, ya desplazado de su potencia interpretativa, de su central lugar de enunciación y de su reconocimiento público. Se trata de un yo desterritorializado, fuera de lugar.

\section{Cierre}

Las escrituras autobiográficas de Fabio Morábito y Sergio Pitol poseen diversos puntos de contacto. Sus obras construyen figuras autorales que ponen en duda las convenciones clásicas de la autobiografía y al mismo tiempo producen espacios textuales difíciles de clasificar, lo que contribuye a una noción disgregada de la identidad, una epistemología de la complejidad y una puesta 
en duda de las jerarquías autorales de la narración. En otras palabras, tanto Pitol como Morábito trabajan con retóricas autobiográficas inestables y formas de figuración autocríticas que son, en el fondo, expresiones del descentramiento del intelectual en el campo cultural mexicano. Tal descentramiento está relacionado no solamente con la crisis de representación intrínseca a la escritura contemporánea, sino con la precariedad biográfica del yo (Bauman, 2001) o la precarización subjetiva (Reguillo, 2010), es decir, con la imposibilidad cada vez mayor que tienen los sujetos contemporáneos de narrar su vida y darle sentido a través de ese relato, frente al sinsentido y amenazas crecientes del mundo que los rodea. En el caso del escritor, tal precarización se expresa como pérdida de seguridad en torno a la autoridad de su propia voz. De ahí que muchos retratos autobiográficos recientes en México (los de Morábito y Pitol, pero también los de Mario Bellatin o Guadalupe Nettel) sean perspectivas autocríticas, imágenes de algún modo rotas, expresiones de una impotencia.

Frente a la precarización referida, es posible observar dos respuestas enarboladas por las obras estudiadas. El mago de Viena combate la pérdida de autoridad y centralidad del letrado, a través de un desplazamiento del yo y una reproducción múltiple de las memorias, que otorga al lector un lugar central en el desciframiento de la historia personal. De igual modo, remarca la historicidad de la verdad y el perspectivismo desde el cual ésta se construye, lo que reduce la distancia entre autor y público. Si no hay versiones definitivas ni autoconocimiento autorizado, Pitol celebra la caída del intelectual como intérprete privilegiado de lo real, mediante el autoescarnio lúcido y la invitación al lector para que entre en el juego y se posicione de manera más horizontal frente el texto que tiene en sus manos.

Por su parte, El idioma materno formula un dispositivo estético distinto que busca resistir a la precarización del yo. Si en varios apartados Morábito reflexiona sobre el estilo como una vocación y un destino, también le adjudica una función salvadora: así como un personaje preserva la vida en el reiterado y fracasado intento por redactar la carta suicida perfecta, en otro momento las palabras dichas en el instante oportuno y con la eficacia precisa evitan que el narrador sea asesinado. El estilo aparece como defensa frente al mundo, como refugio frente a una amenaza exterior. El libro mismo está construido bajo 
ese ethos de la escritura: lo que llama la atención es la dimensión análoga de los fragmentos, así como su polisémica brevedad. La estructura del volumen constituye un ejercicio ejemplar de condensación e intensidad de la escritura. Si se trata, como ha dicho Isaac Magaña, de "un libro contra la acumulación" (2014) y el dispendio de palabras, semánticamente los fragmentos se alimentan unos a otros y sí que se vuelven depósitos de sentido. Se ha celebrado mucho la búsqueda de perfección estilística que practica Morábito, pero aquí adquiere una relevancia no sólo artística sino pública o política. Su estética depurada es al mismo tiempo recuperación de formas clásicas y puesta en escena de incertidumbres contemporáneas: en ese espacio conflictivo es donde el yo, alejándose del solipsismo y poniendo sobre la mesa sus limitaciones, puede volver a ofrecer su mirada como problematización del mundo que lo rodea.

Como puede observarse, en Pitol se apela más a la multiplicidad de los textos y las interpretaciones para mostrar la dificultad para narrar el yo y el pasado. En Morábito, aunque la forma se presenta también desde la fragmentación y el autoescarnio, se apela a la restitución de un texto depurado y no a la reproducción infinita que disgrega una y otra vez el sentido. Frente a la escritura compulsiva y acumulativa de Pitol, Morábito ofrece la depuración formal como un modo de frenar la compulsión y la acumulación de lo escrito. Si existen líneas de continuidad entre ambos autores, también es visible un cambio generacional que estaría subrayando la preocupación actual por recuperar cierta especificidad de lo literario. En este sentido, podría pensarse que la pregunta que Morábito se hace respecto a lo autobiográfico no es ya ¿cómo puede transmitirse la ausencia de verdad respecto de la propia vida?, sino ¿cómo debe transmitirse el valor de la vida ajena que está contenida en el relato del yo? En otras palabras: ya no se trataría para Morábito de llevar un desplazamiento hacia el otro para hablar de uno mismo, sino de depurar las palabras con las cuales entrar en contacto con el otro que hay en el propio yo.

Al hablar sobre la autobiografía contemporánea, Cristina Rivera Garza afirma que más que el relato de un yo, constituye "un testimonio de la radical opacidad del yo consigo mismo", de ahí que en una autobiografía el recuento de uno mismo, tendría por fuerza que enunciarse en una forma narrativa que diera testimonio de tal modo relacional de la vulnerabilidad humana. Una 
autobiografía, en ese sentido, tendría que ser el testimonio de un desconocimiento [...] una biografía del otro tal como aparece, en modo enigmático, en mí. Y eso y no otra cosa sería una autobiografía desposeída sobre el dominio de lo propio (2013: 63-64).

Me parece que eso es justo lo que ocurre en El idioma materno y es lo que explica los ejercicios de apropiación que aparecen en su interior. En cualquier caso, tanto Pitol como Morábito buscan evitar el narcisismo escritural y el tono apologético que florecen, de manera frecuente, en las autobiografías tradicionales. Más allá de sus diferencias, lo valioso es que ambos escritores contribuyen con sus autofiguraciones a desestabilizar una serie de nociones asociadas a la idea de autor, que siguen siendo hegemónicas en el panorama cultural mexicano (entre ellas, las ideas de originalidad, propiedad, autoridad, genialidad, individualismo...). Pitol y Morábito escriben contra la idea romántica de autoría - y las viejas fórmulas cerradas del nacionalismo cultural en que ésta se inscribe-. No es extraño que tal cuestionamiento emerja de dos escritores que poseen fuertes lazos con otras culturas y que tienen como uno de sus oficios fundamentales la traducción. El narcisismo del yo es una forma del nacionalismo cultural. Y la apertura al otro resulta un modo de cruzar fronteras, reducir jerarquías y evidenciar las murallas del sistema autoral vigente.

\section{Referencias bibliográficas}

Alberca, Manuel (2007): El pacto ambiguo. De la novela autobiográfica a la autoficción (pról. Justo Navarro). Madrid: Biblioteca Nueva.

Bauman, Zygmunt (2001): La sociedad individualizada. Madrid: Cátedra.

Beltrán FÉlix, Geney (2015): "Ver criaturas y no cosas". En Letras Libres. Núm. 196, abril, pp. 36-38.

CASAS, Ana (2010): "La construcción del discurso autoficcional: procedimientos y estrategias". En Vera Toro, Sabine Schlickers, y Ana Luengo (eds.), La obsesión del yo. La auto(r)ficción en la literatura española y latinoamericana. Madrid / Fráncfort: Iberoamericana / Vervuert, 193-211. 
Domínguez Michael, Christopher (2007): “Pitol, Sergio”. En Diccionario crítico de la literatura mexicana (1955-2005). México: Fondo de Cultura Económica, pp. 410-416.

Guerra, Humberto (2007): "La estructuración espacial de la Autobiografía de Sergio Pitol". En Teresa García Díaz (coord.), Victorio Ferri se hizo mago en Viena. Sobre Sergio Pitol. Xalapa: Universidad Veracruzana, pp. 315-328.

Lejeune, Phillipe (1994): El pacto autobiográfico y otros estudios. Madrid: Megazul / Endymion.

López Torres, Nora Danira (2015): El desfile del amor al compás del carnaval: parodia y autoparodia. Tesis doctoral. México: El Colegio de México.

Louis, Annick (2010): “Sin pacto previo explícito: el caso de la autoficción”. En Toro Vera, Sabine Schlickers y Ana Luengo (eds.), La obsesión del yo. La auto(r)ficción en la literatura española y latinoamericana. Madrid / Fráncfort: Iberoamericana / Vervuert, pp. 73-96.

Loureiro, Ángel G. (1991): "Problemas teóricos de la autobiografía". En AA. VV., La autobiografía y sus problemas teóricos. Estudios de investigación documental, Barcelona: Anthropos (Suplementos Anthropos, 29), pp. 2-8.

MAGaÑa GCANTón, Isaac (2014): “Las palabras también son semblante”. En Letras Libres, 16 de junio.

Monsiváis, Carlos (2008): “Prólogo. 'Todo está en todo’. Diálogo con Sergio Pitol”. En Sergio Pitol, Obras reunidas. V. Ensayos. México: Fondo de Cultura Económica, pp. 11-18.

Montelongo, Alfonso (2007): “Asimetría' en la obra de Pitol”. En Teresa García Díaz (coord.), Victorio Ferri se hizo mago en Viena. Sobre Sergio Pitol. Xalapa: Universidad Veracruzana, pp. 93-107.

Morábito, Fabio (1989a): Caja de herramientas. México: Fondo de Cultura Económica.

MorÁbito, Fabio (1989b): La lenta furia. México: Vuelta. 
Morábito, Fabio (2000): La vida ordenada. México: Tusquets.

MorÁbito, Fabio(2004): También Berlín se olvida. México: Tusquets.

Morábito, Fabio (2006): Grieta de fatiga. México: Tusquets.

Morábito, Fabio (2014): El idioma materno. México: Sexto Piso.

Neumann, Birgit (2008): “The Literaty Representation of Memory”. En Astrid Erll, y Ansgar Nünning (eds.). Cultural Memory Studies. An Internacional and Interdisciplinary Handbook. Berlín: Walter de Gruyter, pp. 333-343.

Piglia, Ricardo (1999): Formas breves. Buenos Aires: Temas.

Pitol, Sergio (1967): Sergio Pitol. México: Empresas Editoriales.

Pitol, Sergio (1972): El tañido de una flauta. México: Era.

Pitol, Sergio (1996): El arte de la fuga. México: Era.

Pitol, Sergio (2006a): “Autobiografía precoz”. En Obras reunidas. IV. Escritos autobiográficos. México: Fondo de Cultura Económica, pp. 13-40.

Pitol, Sergio (2006b): El mago de Viena [2005]. Bogotá: Fondo de Cultura Económica / Pre-Textos.

Pitol, Sergio (2006c): Obras reunidas. IV. Escritos autobiográficos. México:Fondo de Cultura Económica.

Pitol, Sergio (2007): Trilogía de la Memoria [El arte de la fuga, El viaje, El mago de Viena]. Barcelona: Anagrama.

Pitol, Sergio (2010): Una autobiografía soterrada (ampliaciones, rectificaciones y desacralizaciones). Oaxaca: Almadía.

Pitol, Sergio (2011): Memoria 1933-1966. México: Era.

Reguillo, Rossana (2010): "La condición juvenil en el México contemporáneo". En Rossana Reguillo (coord.), Los jóvenes en México. México: Fondo de Cultura Económica, pp. 395-429. 
Rivera Garza, Cristina (2013): Los muertos indóciles. Necroescrituras y desapropiación. México: Tusquets.

SARACENI, Gina (2015): “El ruido menor. Poesía y sonoridad en la obra de Fabio Morábito". En El jardín de los poetas. Revista de teoría y crítica de poesía latinoamericana. Núm. 1, segundo semestre, pp. 54-70.

STEINER, George (2002): Extraterritorialidad. Ensayos sobre literatura y revolución lingüística [1972]. Madrid: Siruela.

Villoro, Juan (2000): “Pitol: los anteojos perdidos”. En Efectos personales. México: Era, pp. 52-58. 